\title{
Haematological values for captive harpy eagle (Harpia harpyja) ${ }^{1}$
}

\author{
Marcos J. Oliveira ${ }^{2}$, Isalina A. Nascimento ${ }^{3}$, Vanessa O. Ribeiro ${ }^{4 *}$, Luiz A. Cortes ${ }^{3}$, \\ Rene D. Fernandes ${ }^{3}$, Leonilda C. Santos ${ }^{5}$, Wanderlei Moraes ${ }^{2}$ and Zalmir S. Cubas ${ }^{2}$
}

\begin{abstract}
Oliveira J.O., Nascimento I.A., Ribeiro V.O., Cortes L.A., Fernandes R.D., Santos L.C., Moraes W. \& Cubas Z.S. 2014. Haematological values for captive harpy eagle (Harpia harpyja). Pesquisa Veterinária Brasileira 34(8):805-809. Protected Areas Division, Itaipu Binacional, Av. Tancredo Neves 6731, Foz do Iguaçu, PR 85866-900, Brazil. E-mail: marcosjo@itaipu.gov.br

Decreasing of harpy eagle (Harpia harpyja) populations in natural environments, mainly in non-preserved areas, makes captive population management an important contribution to genetic diversity conservation. The aim of this study is to evaluate hematological parameters for captive harpy eagles maintained at the wild animals breeding center of Itaipu Binacional, Paraná State, Brazil. Fourteen blood samples from nine harpy eagles were collected from animals of both sexes, of different ages and with no clinical signs of disease. Significant variations were found in haematological values of hematocrit, hemoglobin, mean corpuscular hemoglobin (MCH), mean corpuscular hemoglobin concentration (MCHC), leukocyte, a relative number of heterophils, absolute and relative number of lymphocytes, monocytes, eosinophils, basophils and plasma protein between groups of young (less than six months old) and adult birds. Comparing males and females there was variation in the values of erythrocytes, hemoglobin, mean corpuscular volume (MCV), mean corpuscular hemoglobin (MCH) on heterophils, absolute and relative number of lymphocytes, eosinophils and basophils. There was also variation in the values of red blood cells, hematocrit, hemoglobin, mean corpuscular volume (MCV), mean corpuscular hemoglobin (MCH), mean corpuscular hemoglobin concentration (MCHC), leukocyte count, absolute number of lymphocytes, eosinophils and basophils among birds that study compared to another reference birds. Due to the limited information available on harpy eagle hematology, this study will be useful to the clinical assessment of birds maintained in captivity.
\end{abstract}

INDEX TERMS: Hematology, harpy eagle, Harpia harpyja, avian, raptors, conservation.

RESUMO.- [Valores hematológicos para águia hapia (Harpia harpyja) em cativeiro.] A diminuição de populações de harpia (Harpia harpyja) em ambientes naturais, principalmente em áreas não preservadas, torna a gestão população cativa uma contribuição importante para a con-

\footnotetext{
${ }^{1}$ Received on February 3, 2014.

Accepted for publication on July 28, 2014.

${ }^{2}$ Protected Areas Division, Itaipu Binacional, Av. Tancredo Neves 6731, Foz do Iguaçu, PR 85866-900, Brazil.

${ }^{3}$ Environmental Action Division, Itaipu Binacional, Av. Tancredo Neves 6731, Foz do Iguaçu, PR 85866-900.

${ }^{4}$ Veterinarian, Rua Maria José Notini 220, Divinópolis, MG 35501-097, Brazil. *Corresponding author: vanessa.oribeiro@yahoo.com.br

${ }^{5}$ Centro de Engenharias e Ciências Exatas (CECE), Universidade Estadual do Oeste do Paraná (Unioeste), Fundação Parque Tecnológico de Itaipu (FPTI) , Av. Tancredo Neves 6731, Bloco 5, Espaço 3, Foz do Iguaçu, PR 85866-900, Brazil.
}

servação da diversidade genética. 0 objetivo deste estudo é avaliar os parâmetros hematológicos de harpias em cativeiro mantidas para os animais selvagens de reprodução centro da Itaipu Binacional, Paraná, Brasil. Quatorze amostras de sangue de nove harpias foram coletadas de animais de ambos os sexos, de diferentes idades e sem sinais clínicos da doença. Variações significativas foram encontradas nos valores hematológicos de hematócrito, hemoglobina, hemoglobina corpuscular média (HCM), concentração de hemoglobina corpuscular média (CHCM), de leucócitos, um número relativo de heterófilos, absoluta e número relativo de linfócitos, monócitos, eosinófilos, basófilos e proteínas plasmáticas entre grupos de jovens (menos de seis meses de idade) e adultos aves. Comparando homens e mulheres houve variação nos valores de eritrócitos, hemoglobina, volume corpuscular médio (VCM), hemoglobina corpuscular média (HCM) em heterófilos, o número absoluto e re- 
lativo de linfócitos, eosinófilos e basófilos. Houve também variação nos valores de células vermelhas do sangue, hematócrito, hemoglobina, volume corpuscular médio (VCM), hemoglobina corpuscular média (HCM), concentração de hemoglobina corpuscular média (CHCM), contagem de leucócitos, número absoluto de linfócitos, eosinófilos e basófilos entre aves que estudam em comparação com outras aves de referência. Devido à pouca informação disponível sobre hematologia harpia, este estudo será útil para a avaliação clínica das aves mantidas em cativeiro.

TERMOS DE INDEXAÇÃO: Hematologia, águia harpia, Harpia harpyja, aviário, aves de rapina, conservação.

\section{INTRODUCTION}

The harpy or harpy eagle is a bird belonging to the Order Accipitriformes, family Accipitridae, and it is the largest bird of prey in Brazil (Sick 1988, CBRO 2010). It is widely spread in Central and South America, from Mexico to northern Argentina and Brazil (Vargas et al. 2006). And is usually found in large tracts of unspoilt forests, where may be established viable populations (Thiollay 1989).

According to IUCN (2008), the harpy eagle is near threatened and accordind to CITES (2010) it is endangered, they consider hunting and habitat loss as the main causes of population decline.

Considering this species population decline, strategies from conservation to maintenance of regional populations are important to preserve the genetic diversity (Lerner et al. 2009), also important is the development of scientific research to achieve knowledge about the species' biology and reproductive physiology and the maintenance of population ex situ. For the maintenance of healthy animals in captivity is essential to adopt disease prevention programs and knowledge of physiological parameters, such as the haematological values, which aid in the early diagnosis of diseases and allow monitoring the clinical progress of patients (Mitchell \& Johns 2008).

The aim of this study is to evaluate hematological parameters for captive harpy eagles maintained at a specific Brazilian center and compare them with the hematological parameters published by other authors.

\section{MATERIALS AND METHODS}

Fourteen blood samples from nine different animals were analyzed separated into two groups: six of them from animals aged up to six months and eight samples from animals older than six months, disgarding their gender. The age of six months was set as the limit of classification between the groups by considering that the birds at this age have reached the weight of an adult bird and they have plumage that allows the flight. Samples were collected from July 2003 to May 2012, from animals with no clinical signs of disease. All animals were kept in the Wild Animals Breeding of Itaipu Binacional, in Foz do Iguaçu, Paraná, Brazil. The birds aged up to 90 days were fed with carcasses of rats and rabbits raised for this purpose, which were killed humanely and provided skinless. From 90 days on, they were fed with carcasses of rats and rabbits with skin and hair, which were raised at the institution as allowed by IBAMA's register, number 1286483.
To collect the samples, the birds were captured in the ponds with the help of a netting, their view was obstructed by a hooded falconry and the birds were physically contained for blood collection through the ulnar, medial or metatarsal veins, using a heparinized syringe. The samples were then kept under refrigeration until they were transported and processed immediately in the Environmental Laboratory of Itaipu Binacional, in a maximum of six hours after the collection, according to usual hematological techniques described by Santos (1999).

We evaluated: number of erythrocytes, hematocrit, hemoglobin, mean corpuscular volume (MCV), mean corpuscular hemoglobin $(\mathrm{MCH})$, mean corpuscular hemoglobin concentration (MCHC), leukocyte, absolute and relative number of heterophile, eosinophils, lymphocytes, basophils, monocytes and plasma protein.

For statistical analyzes of the results we used Man-Whitney's methods, ANOVA with test $\mathrm{t}$ as post hoc and test " $\mathrm{t}$ " as Student with significance level of $95 \%$ by the program BioEstat $\AA$. Calculations of average statistical description and the standard deviation were made in Excel $^{\circledR}$.

\section{RESULTS}

Regarding age groups (young and adult birds), there was significant variation $(\mathrm{p}<0.05)$ for hematological numbers. In young animals were significantly higher the values of hemoglobin $(10.57 \pm 1.40)$, mean corpuscular hemoglobin $(\mathrm{MCH})(79.60 \pm 28.1)$, mean corpuscular hemoglobin concentration $(\mathrm{MCHC})(32.60 \pm 1.48)$, leukocyte $(18.19 \pm 5.40)$ and absolute and relative number of eosinophils $(3.37 \pm 1.19$ and $18.33 \pm 3.50)$ and lymphocytes $(5.77 \pm 2.60$ and $31.50 \pm 9.00)$. In adult animals were significantly higher values of hematocrit $(34.25 \pm 2.19)$, absolute and relative numbers of basophils $(0.14 \pm 0.20$ and $1.00 \pm 1.41)$ and monocytes $(0.33 \pm 0.29$ and $2.86 \pm 3.04)$, relative number of heterophile (66.00 \pm 8.05$)$ and plasma protein $(5.60 \pm 0.39)$.

Table 1. Hematological values for females and males, young and adults harpies (Harpia harpyja) kept in the Wild Animals Breeding from Itaipu Binacional in Foz do Iguaçu, Paraná, Brazil

\begin{tabular}{|c|c|c|c|c|c|c|c|}
\hline Parameter & Unit & Average & $\begin{array}{l}\text { Standard } \\
\text { deviation }\end{array}$ & $\begin{array}{c}\text { Minimum } \\
\text { limit }\end{array}$ & $\begin{array}{c}\text { Maximum } \\
\text { limit }\end{array}$ & $\mathrm{N}$ & $\mathrm{n}$ \\
\hline RBCs & $10^{6} / \mu \mathrm{L}$ & 1,47 & 0,26 & 1,21 & 1,74 & 14 & 9 \\
\hline Hematocrit & $\%$ & 33 & 2,74 & 30,69 & 36,17 & 14 & 9 \\
\hline Hemoglobin & $\mathrm{g} / \mathrm{dL}$ & 9,55 & 2,08 & 7,47 & 11,63 & 14 & 9 \\
\hline MCV & $\mathrm{fL}$ & 234,86 & 52,38 & 182,47 & 287,24 & 14 & 9 \\
\hline $\mathrm{MCH}$ & pg & 67,48 & 23,56 & 43,92 & 91,04 & 14 & 9 \\
\hline $\mathrm{MCHC}$ & $\%$ & 28,74 & 6,42 & 22,32 & 35,16 & 14 & 9 \\
\hline Leukocytes & $10^{3} / \mu \mathrm{L}$ & 16,52 & 5,36 & 11,16 & 21,89 & 14 & 9 \\
\hline Heterophile & $\%$ & 58,86 & 11,11 & 47,75 & 69,96 & 14 & 9 \\
\hline Heterophile & $10^{3} / \mu \mathrm{L}$ & 9,67 & 3,55 & 6,12 & 13,22 & 14 & 9 \\
\hline Lymphocytes & $\%$ & 24,07 & 9,52 & 14,55 & 33,59 & 14 & 9 \\
\hline Lymphocytes & $10^{3} / \mu \mathrm{L}$ & 4,02 & 2,34 & 1,69 & 6,36 & 14 & 9 \\
\hline Monocytes & $\%$ & 2,00 & 2,51 & 0 & 4,51 & 14 & 9 \\
\hline Monocytes & $10^{3} / \mu \mathrm{L}$ & 0,24 & 0,24 & 0 & 0,49 & 14 & 9 \\
\hline Eosinophils & $\%$ & 14,50 & 6,38 & 8,12 & 20,88 & 14 & 9 \\
\hline Eosinophils & $10^{3} / \mu \mathrm{L}$ & 2,51 & 1,50 & 1,00 & 4,00 & 14 & 9 \\
\hline Basophils & $\%$ & 0,57 & 1,16 & 0 & 1,73 & 14 & 9 \\
\hline Basophils & $10^{3} / \mu \mathrm{L}$ & 0,08 & 0,16 & 0 & 0,24 & 14 & 9 \\
\hline PP & $\mathrm{g} / \mathrm{dL}$ & 5,24 & 0,56 & 4,68 & 5,80 & 14 & 9 \\
\hline
\end{tabular}

MCV = Mean Corpuscular Volume; $\mathrm{MCH}=$ Mean Corpuscular Hemoglobin; MCHC = Mean Corpuscular Hemoglobin Concentration; PP = Plasm Protein; $\mathrm{N}=$ Number of blood sample; $\mathrm{n}=$ Number of animals. 
Table 2. Hematological values by age for males and females harpies (Harpia harpyja) kept in the Wild Animals Breeding from Itaipu Binacional in Foz do Iguaçu, Paraná, Brazil

\begin{tabular}{|c|c|c|}
\hline \multirow[t]{2}{*}{ Parameter } & \multirow{2}{*}{$\begin{array}{c}\text { Young birds }{ }^{\mathrm{a}}(\mathrm{N}=6) \\
\text { Average (Standard } \\
\text { deviation) }\end{array}$} & \multirow{2}{*}{$\begin{array}{c}\text { Adult birds }^{\mathrm{b}}(\mathrm{N}=8) \\
\text { Average (Standard } \\
\text { deviation) }\end{array}$} \\
\hline & & \\
\hline $\operatorname{RBCs}\left(10^{6} / \mu \mathrm{L}\right)$ & $1,42(0,34)$ & $1,51(0,21)$ \\
\hline Hematocrit (\%) ${ }^{c}$ & $32,33(3,20)$ & $34,25(2,19)$ \\
\hline Hemoglobin $(\mathrm{g} / \mathrm{dL})^{\mathrm{c}}$ & $10,57(1,40)$ & $8,78(2,24)$ \\
\hline MCV (fL) & $241,70(75,55)$ & $229,72(30,78)$ \\
\hline MCH (pg) ${ }^{c}$ & $79,60(28,31)$ & $58,39(15,44)$ \\
\hline $\mathrm{MCHC}(\%)^{\mathrm{c}}$ & $32,60(1,48)$ & $25,84(7,25)$ \\
\hline Leukocytes $\left(10^{3} / \mu \mathrm{L}\right)^{\mathrm{c}}$ & $18,19(5,40)$ & $15,26(5,33)$ \\
\hline Heterophile $(\%)^{c}$ & $49,33(6,28)$ & $66,00(8,05)$ \\
\hline Heterophile $\left(10^{3} / \mu \mathrm{L}\right)$ & $8,92(2,51)$ & $10,24(4,25)$ \\
\hline Lymphocytes (\%) ${ }^{c}$ & $31,50(9,00)$ & $18,50(5,26)$ \\
\hline Lymphocytes $\left(10^{3} / \mu \mathrm{L}\right)^{\mathrm{c}}$ & $5,77(2,60)$ & $2,71(0,86)$ \\
\hline Monocytes $(\%)^{c}$ & $0,83(0,75)$ & $2,86(3,04)$ \\
\hline Monocytes $\left(10^{3} / \mu \mathrm{L}\right)^{\mathrm{c}}$ & $0,13(0,11)$ & $0,33(0,29)$ \\
\hline Eosinophils (\%) ${ }^{\mathrm{c}}$ & $18,33(3,50)$ & $11,63(6,70)$ \\
\hline Eosinophils $\left(10^{3} / \mu \mathrm{L}\right)^{\mathrm{c}}$ & $3,37(1,19)$ & $1,85(1,43)$ \\
\hline Basophils (\%) ${ }^{c}$ & 0 & $1,00(1,41)$ \\
\hline Basophils $(103 / \mu \mathrm{L})^{\mathrm{c}}$ & 0 & $0,14(0,20)$ \\
\hline$P P(g / d L)^{c}$ & $4,77(0,37)$ & $5,60(0,39)$ \\
\hline
\end{tabular}

$\overline{\mathrm{MCV}}=$ Mean Corpuscular Volume; $\mathrm{MCH}=$ Mean Corpuscular Hemoglobin; $\mathrm{MCHC}=$ Mean Corpuscular Hemoglobin Concentration; PP = Plasm Protein; $\mathrm{N}=$ Number of blood sample; ${ }^{\mathrm{a}}$ Birds aged until six months; ${ }^{\mathrm{b}}$ Birds older than six months; ${ }^{\mathrm{c}}$ Parameters with significant variation $(\mathrm{p}<0,05)$ between the age groups.

Table 3. Hematological values by gender for harpies (Harpia harpyja) kept in the Wild Animals Breeding from Itaipu Binacional in Foz do Iguaçu, Paraná, Brazil

\begin{tabular}{|c|c|c|}
\hline \multirow[t]{2}{*}{ Parameter } & Females(N=8) & Males(N=6) \\
\hline & $\begin{array}{c}\text { Average (Standard } \\
\text { deviation) }\end{array}$ & $\begin{array}{c}\text { Average (Standard } \\
\text { deviation) }\end{array}$ \\
\hline $\operatorname{RBCs}\left(10^{6} / \mu \mathrm{L}\right)^{\mathrm{d}}$ & $1,54(0,22)$ & $1,38(0,29)$ \\
\hline Hematocrit (\%) & $33,36(3,62)$ & $33,50(1,05)$ \\
\hline Hemoglobin $(\mathrm{g} / \mathrm{dL})^{\mathrm{d}}$ & $9,40(1,67)$ & $9,74(2,69)$ \\
\hline $\operatorname{MCV}(\mathrm{fL})^{\mathrm{d}}$ & $221,54(45,05)$ & $252,61(60,26)$ \\
\hline $\mathrm{MCH}(\mathrm{pg})^{\mathrm{d}}$ & $62,93(18,61)$ & $73,55(29,69)$ \\
\hline $\operatorname{MCHC}(\%)^{\mathrm{d}}$ & $28,53(5,76)$ & $29,03(7,78)$ \\
\hline Leukocytes $\left(10^{3} / \mu \mathrm{L}\right)$ & $16,16(4,78)$ & $16,99(6,51)$ \\
\hline Heterophile $(\%)^{\mathrm{d}}$ & $60,86(10,60)$ & $56,17(12,14)$ \\
\hline Heterophile $\left(10^{3} / \mu \mathrm{L}\right)$ & $10,07(4,25)$ & $9,14(2,62)$ \\
\hline Lymphocytes (\%) $)^{\mathrm{d}}$ & $19,50(7,65)$ & $30,17(8,70)$ \\
\hline Lymphocytes $\left(10^{3} / \mu \mathrm{L}\right)^{\mathrm{d}}$ & $3,05(1,09)$ & $5,32(3,00)$ \\
\hline Monocytes (\%) & $2,25(2,80)$ & $1,67(2,25)$ \\
\hline Monocytes $\left(10^{3} / \mu \mathrm{L}\right)$ & $0,28(0,28)$ & $0,20(0,21)$ \\
\hline Eosinophils (\%) ${ }^{\mathrm{d}}$ & $16,36(6,41)$ & $12,00(5,93)$ \\
\hline Eosinophils $\left(10^{3} / \mu \mathrm{L}\right)^{\mathrm{d}}$ & $2,63(1,36)$ & $2,33(1,79)$ \\
\hline Basophils (\%) ${ }^{\mathrm{d}}$ & $1,00(1,41)$ & $0,00(0,00)$ \\
\hline Basophils $\left(10^{3} / \mu \mathrm{L}\right)^{\mathrm{d}}$ & $0,14(0,20)$ & $0,00(0,00)$ \\
\hline$P P(g / d L)$ & $5,33(0,56)$ & $5,13(0,56)$ \\
\hline
\end{tabular}

$\mathrm{MCV}=$ Mean Corpuscular Volume; $\mathrm{MCH}=$ Mean Corpuscular Hemoglobin; MCHC = Mean Corpuscular Hemoglobin Concentration; PP = Plasm Protein; $\mathrm{N}=$ Number of blood sample; ${ }^{\mathrm{d}}$ Parameters with significant variation $(\mathrm{p}<0,05)$ between genders.

When it comes to gender, there was significant variation $(\mathrm{p}<0.05)$ on the haematological values. In females the values of erythrocytes $(1.54 \pm 0.22)$, relative number of heterophile $(60.86 \pm 10.60)$, absolute and relative numbers of basophils $(0.14 \pm 0.20$ e $1.00 \pm 1.41)$ and eosinophils $(2.63 \pm 1.36$ and $16.36 \pm 6.41)$ were significantly higher. In the males were significantly higher the values of he-
Table 4. Hematological values for males and females harpies (Harpia harpyja) at the current study and on ISIS (2002)

\begin{tabular}{|c|c|c|c|c|}
\hline Parameter & Current study & $\mathrm{N}$ & ISIS (2002) & $\mathrm{N}$ \\
\hline & $\begin{array}{c}\text { Average } \\
\text { (Standard deviation) }\end{array}$ & & $\begin{array}{c}\text { Average } \\
\text { (Standard deviation) }\end{array}$ & \\
\hline $\operatorname{RBCs}\left(10^{6} / \mu \mathrm{L}\right)^{\mathrm{e}}$ & $1,47(0,26)$ & 14 & $1,58(0,21)$ & \\
\hline Hematocrit $(\%)^{\mathrm{e}}$ & $33,00(2,74)$ & 14 & $35,00(3,90)$ & 26 \\
\hline Hemoglobin $(\mathrm{g} / \mathrm{dL})^{\mathrm{e}}$ & $9,55(2,08)$ & 14 & $17,60(13,40)$ & 3 \\
\hline $\mathrm{MCV}$ & 234,86 & 14 & $213,10(16$ & 8 \\
\hline $\mathrm{MCH}$ & 67,48 & 14 & 244,40 & \\
\hline $\mathrm{MCH}$ & 28,7 & 14 & $28,40(1,2$ & 2 \\
\hline es $\left(10^{3} / \mu \mathrm{L}\right)^{\mathrm{e}}$ & 16,5 & 14 & $13,20(10,90)$ & 19 \\
\hline Heter & 58,86 & 14 & & \\
\hline $\left.3^{3} / \mu \mathrm{L}\right)$ & 9,67 & 14 & $8,91(7,39)$ & 19 \\
\hline Lymp & 24,07 & 14 & - & - \\
\hline ocytes $\left(10^{3} / \mu \mathrm{L}\right)^{\mathrm{e}}$ & $4,02(2$ & 14 & $2,67(2,60)$ & 19 \\
\hline Mon & $2,00(2,51)$ & 14 & - & - \\
\hline $\mathrm{s}\left(10^{3} / \mu \mathrm{L}\right)$ & $0,24(0,24)$ & 14 & $0,27(0,33)$ & 7 \\
\hline ils $(\%)$ & $14,50(6,38)$ & 14 & 年 & \\
\hline Eosinophils $\left(10^{3} / \mu \mathrm{L}\right)^{\mathrm{e}}$ & $2,51(1,50)$ & 14 & $1,20(0,95)$ & 12 \\
\hline Baso & $0,57(1,16)$ & 14 & - & \\
\hline Basophils $\left(10^{3} / \mu \mathrm{L}\right)^{\mathrm{e}}$ & $0,08(0,16)$ & 14 & $0,23(0,12)$ & \\
\hline $\mathrm{PP}(\mathrm{g} / \mathrm{dL})$ & $5,24(0,56)$ & 14 & - & - \\
\hline
\end{tabular}

MCV = Mean Corpuscular Volume; $\mathrm{MCH}=$ Mean Corpuscular Hemoglobin; MCHC = Mean Corpuscular Hemoglobin Concentration; PP = Plasm Protein; $\mathrm{N}=$ Number of blood sample; ${ }^{\text {e }}$ Parameters with significant variation $(\mathrm{p}<0,05)$ between the current study and ISIS values (2002).

moglobin $(9.74 \pm 2.69)$, mean corpuscular volume (MCV) (252.61 \pm 60.26$)$, mean corpuscular hemoglobin $(\mathrm{MCH})$ (73.55 \pm 29.69$)$, mean corpuscular hemoglobin concentration (MCHC) $(29.03 \pm 7.78)$ and absolute and relative number of lymphocytes $(5.32 \pm 3.00$ and $30.17 \pm 8.70)$.

Adult females had higher plasma protein values than the others $(5.33 \pm 0.56)$, showing significant variation when compared to younger animals of both gender. There was also significant variation between males when comparing the younger ones with adults, the higher values were the adults ones (5.60 \pm 0.39$)$. The results are shown in Table 1-4.

Comparing statistically the results of this study with parameters determined by the $\mathrm{CBC}$ for harpy of the International Species Information System ISIS (2002), we can see a significant variation $(\mathrm{p}<0,05)$ between the values of RBCs, hematocrit, hemoglobin, mean corpuscular volume (MCV), mean corpuscular hemoglobin (MCH), leukocyte, absolute number of basophils, eosinophils and lymphocytes.

\section{DISCUSSION}

Studies realized in vultures (several species) and several species of owls, eagles and hawks (Smith \& Bush 1978, Hernandez et al. 1990) showed a higher number of erythrocytes and lower MCV that those found in this harpy study. As birds of larger size tend to have low numbers of red blood cells (Balash et al. 1974), this difference can be attributed to the size of species Harpy harpyja

The average hematocrit found in harpy was lower than the normal for birds in general, which commonly is 35-55\% (Smith \& Bush 1978, Hernandez et al. 1990, Campbell 1994, Padrtova \& Lloyd 2009). But there are values below this parameter in studies of other species of predators (Balash et al. 1976, ISIS 2002). Low hematocrit can indicate anemia resulting from trauma, parasitism, intoxication, sepsis, ne- 
oplasia, parasite of erythrocytes, immune-mediated diseases and chronic diseases. There are records of a nutritional deficiency anemias in poultry, but proven descriptions are not common in wild birds in captivity, since iron is normally present these birds food (Schmidt et al. 2007a). everal factors, such as time of day and ambient temperature, can significantly alter the hematocrit value, making necessary caution in the interpretation of this parameter (Dawson \& Bortolotti 1997).

Hemoglobin values found in this study were lower than those found in other groups of birds by Celdrán et al. (1994) and lower than those found in the birds of prey (Balash et al. 1976, Pereira 2006). As well as decreased hematocrit, decreased hemoglobin levels in the blood may indicate anemia resulting from various causes (Schmidt et al. 2007a).

Leukocytes, as observed in this study, tend to have higher values in young birds than in adults, and on the birds between four and six months of age we can find great variability in leukocyte (Martinez et al. 2009).

The lymphocytes are the predominant leukocytes in some species of birds, that doesn't look the same when observed the birds os prey, in which heterophile outnumber. Heterophilic respond nonspecifically to stressors, such as infection, exposure to cold, riboflavin deficiency, and in general is a fast response and may reflect cell count (Ivins et al. 1986).

Monocytosis is associated with chronic diseases, on the other hand monocytopenia has no clinical significance (Schmidt et al. 2007a). Monocyte cells of birds are sometimes difficult to differentiate from lymphocytes, and variations in the counting of these two cell types may reflect this difficulty(Ivins et al. 1986).

In this study there were high counts of eosinophils, which corroborates with Hernandez et al. (1990), que observaram altos níveis de eosinófilos circulantes não associados a doença clínica em milhafres (Buteo buteo) discoveries. The eosinophil are rare in some species blood count and common in other (Martinez et al. 2009), whereas the function of eosinophils, and basophils in poultry is not fully elucidated (Campbell 1994).

The values of plasma proteins in this study were higher than in birds of various species of the order Psittaciformes, doves (Columbia livia), ducks (Anas platyrhynchos) (Lumeij 1987; Gomes et al. 2011) and emus (Rhea americana) (Conrado et al. 2007), whereas the carnivorous habits would seem to favor the increased values of plasma proteins.

In addition, higher values of plasma proteins in adult females observed in this study and also reported by others authors (Schmidt et al. 2007b) may be associated with raising these values in females lay eggs during the egg production, since there is hyperproteinemia induced by estrogen required for the production of calf (Lumeij 1997).

Changes in haematological parameters between birds of different ages, although observed in several avian species, do not appear to be significant on predators (Gessaman et al. 1986, Dawson \& Bortolotti 1997, Hernández \& Margalida 2010), but in this study there was significant variation in most parameters. Hematocrit values were significantly lower in younger animals, this discovery could be explained by the fact that adult animals require higher oxygen demands for flight (Villegas et al. 2002) or by the fact the young birds are presenting iron deficiency anemia in the moment of collections. However, hemoglobin levels, which are also influenced by oxygen demand (Celdrán et al. 1994), were higher in younger animals. There is disagreement in the literature as to variations in numbers of leukocyte types in terms of age (Abelenda et al. 1993, Schmidt et al. 2007a), it is not possible to infer the reason for such variations in this study.

Studies with birds of prey (Aquila chrysaetos e Circus pygargus) (Nazifi et al. 2008, Limiñana et al. 2009) showed no significant difference between genders in these species. However, the data obtained in this study showed significant variation between haematological values of male and female harpy.

The intraspecific variability of haematological values is caused by the influence of physiological factors as metabolic activity, gender, age, reproductive status, circadian rhythm, season, diet and habitat (Jerzak et al. 2010).

Most parameters obtained for harpy was significantly different from the parameters found in ISIS (2002). This may have occurred because only samples from clinically healthy animals were included in the analysis of this study, while in the ISIS database samples are of animals in indefinite clinical conditions. Furthermore, the sample number of ISIS (2002) is quite irregular, and the mean values for some parameters are only from a sample.

\section{CONCLUSIONS}

Mean haematological values for harpies showed significant variations according to age groups, young and adult birds, and also in relation to gender.

There was also significant variation in relation to values of RBCs, hematocrit, hemoglobin, mean corpuscular volume (MCV), mean corpuscular hemoglobin $(\mathrm{MCH})$, mean corpuscular hemoglobin concentration (MCHC), leukocyte, absolute number of lymphocytes, eosinophils and basophils established in one international database.

The data published in this study can assist the veterinarian in laboratory and clinical assessment of harpies kept in captivity for breeding programs.

Acknowledgements.- Thanks to Civil servants of the Wild Animals Breeding from Itaipu (CASIB) as they made this research possible.

\section{REFERENCES}

Abelenda M., Nava M.P., Fernandez A., Alonso J.A., Alonso J.C., Muñoz-Pulido R., Bautista L.M. \& Puerta M.L. 1993. Blood values of common cranes (Grus grus) by age and season. Comp. Biochem. Physiol. 104:575-578.

Balasch J., Palomeque J., Palacios L., Musquera S. \& Jimenez M. 1974. Hematological values of some great flying and aquatic-diving birds. Comp. Biochem. Physiol. 49:137-145.

Balasch J., Musquera S., Palacios L., Jimenez M. \& Palomeque J. 1976. Comparative hematology of some falconiforms. Condor 78:258-273.

Campbell T.W. 1994. Hematology, p.176-198. In: Ritchie B.W., Harrison J.G. \& Harrison L.R. (Eds), Avian Medicine: Principles and Application. Vol.1. Wingers Publishing, Florida. 1384p.

CBRO 2010. Listas das Aves do Brasil. 9a ed. Comitê Brasileiro de Registros Ornitológicos. Available in <http://www.cbro.org.br> Checked on September 27, 2012. 
Celdrán J., Polo F.., Peinado V.I., Viscor G. \& Palomeque J. 1994. Haematology of captive herons, egrets, spoonbill, ibis and gallinule. Comp. Biochem. Physiol. 107:337-341.

CITES 2010. Convention on International Trade in Endangered Species of Wild Fauna and Flora: appendices I, II and III. Available in <http://www. cites.org/> Checked on August 16, 2012.

Conrado A.C., Lopes S.T.A., Martins D.B., Duarte M.F., Mortari A.C., Flores M.L. \& Barasuól L. 2007. Eletroforese das proteínas plasmáticas em emas (Rhea americana) de diferentes faixas etárias. Ciência Rural 37:1033-1038.

Dawson R.D. \& Bortolotti G.R. 1997. Variation in hematocrit and total plasma proteins of nestling american kestrels (Falco sparverius) in the wild. Comp. Biochem. Physiol. 117:383-390.

Ivins G.K., Weddle G.D. \& Halliwell W.H. 1986. Hematology and serum chemistries in birds of prey, p.434-437. In: Fowler M.E. (Ed.), Zoo and Wild Animal Medicine. Vol.1. W.B. Saunders, Philadelphia. 1127p.

Gessaman J.A., Johnson J.A. \& Hoffman S.W. 1986. Hematocrits and erythrocyte numbers for cooper's and sharp-shinned hawks'. The Condor 88:95-96.

Gomes D.M., Silva M.N., Silva R.M.M., Dórea R.D., Bastos B.L. \& Ayres M.C.C. 2011. Hemograma e bioquímica clínica sanguínea de araras (Ara sp.) mantidas em sítios ecológicos no estado da Bahia. Ciênc. Anim. Bras. 12:699-711.

Hernandez M., Martin S. \& Fores P. 1990. Clinical hematology and blood chemistry values for the common buzzard (Buteo buteo). J. Raptor Res. 24:113-119.

Hernandez M. \& Margalida A. 2010. Hematology and blood chemistry reference values and age-related changes in wild bearded vultures (Gypaetus barbatus). J. Wildl. Dis. 46:390-400.

ISIS 2002. Available in http://www.isis.org, Checked on October 10, 2012. IUCN 2008. IUCN Red List of Threatened Species. International Species Information System Physiological Data Reference Values. International Union for the Conservation of Nature. Available in <http://www.iucnredlist.org> Checked on August 19, 2012.

Jerzak L., Sparks T.H., Kasprzak M., Bochenski M., Kaminski P., Wisniewska E., Mroczkowski S. \& Tryjanowski P. 2010. Blood chemistry in white storks (Ciconia ciconia) chicks varies by sex and age. Comp. Biochem. Physiol. B 156:144-147.

Lerner H.R.L., Johnson J.A., Lindsay A.R., Kiff L.F. \& Mindell D.P. 2009. It's not too Late for the harpy eagle (Harpia harpyja): high levels of genetic diversity and differentiation can fuel conservation programs. Plos One 4:1-10. DOI: 10.1371 .

Limiñana R., López-Olvera J.R., Gallardo M., Fordham M. \& Urios V. 2009.
Blood chemistry and hematologic values in free-living nestlings of Montagu's Harriers (Circus pygargus) in a natural habitat. J. Zoo Wildl. Med. 40:687-695.

Lumeij J.T. 1987. The diagnostic value of plasma proteins and non-protein nitrogen substances in birds. Vet. Quart. 9:262-268.

Lumeij J.T. 1997. Avian clinical biochemistry, p.857-883. In: Kaneko J.J., Harvey J.W. \& Bruss M.L. (Eds), Clinical Biochemistry of Domestic Animals. Vol.5. Academic Press, San Diego. 932p.

Martinez C.F., Benavides G.F.R. \& Osorio J.H. 2009. El laboratorio clínico en hematología de aves exóticas. Biosalud 8:178-188.

Mitchell E.B. \& Johns J. 2008. Avian hematology and related disorders. Vet. Clin. North Am., Exot. Anim. Pract. 11:501-522.

Nazifi S., Nabinejad A., Sepehrimanesh M., Poorbaghi S.L., Farshneshani F. \& Rahsepar M. 2008. Haematology and serum biochemistry of golden eagle (Aquila chrysaetos) in Iran. Comp. Clin. Pathol. 17:197-201.

Padrtova R. \& Lloyd C.G. 2009. Hematologic values in healthy gyr $\times$ peregrine falcons (Falco rusticolus $\times$ Falco peregrinus). J. Avian Med. Surg. 23:108-113.

Pereira R.J.G. 2006. Falconiformes e Strigiformes (águia, gavião, falcão, abutre, coruja), p.252-267. In: Cubas Z.S., Silva J.C.R \& Catão-Dias J.L. (Eds), Tratado de Animais Selvagens., Vol.1. Roca, São Paulo. 1354p.

Santos L.C. 1999. Laboratório Ambiental. Edunioeste, Cascavel, PR. 341p.

Schmidt E.M.S., Locatelli-Dittrich R., Santin E. \& Paulillo A.C. 2007a. Patologia clínica em aves de produção, uma ferramenta para monitorar a sanidade avícula: revisão. Archs Vet. Sci. 12:9-20.

Schmidt E.M.S., Paulillo A.C., Santin E., Dittrich R.L. \& Oliveira E.G. 2007b. Hematological and serum chemistry values for the ring-necked pheasant (Phasianus colchicus): variation with sex and age. Int. J. Poultry Sci. 6:137-139.

Sick H. 1988. Ornitologia Brasileira: uma introdução. $3^{\underline{a}}$ ed. Universidade de Brasília, Brasília. 827p.

Smith E.E. \& Bush M. 1978. Haematologic parameters on various species of strigiformes and Falconiformes. J. Wildl. Dis. 14:447-450.

Thiollay J.M. 1989. Area requirements for the conservation of rain forest raptors and game birds in French Guiana. Conservation Biol. 3:128-137.

Vargas J.J., Whitacre D., Mosquera R., Albuquerque J., Piana R., Thiollay J-M., Márquez C., Sánchez J.E., Lezama-López M., Midence S., Matola S., Aguilar S., Rettig N. \& Sanaiotti T. 2006. Estado y distribuición actual del águila arpía (Harpia harpyja) en centro y sur América. Ornitología Neotropical 17:39-55.

Villegas A., Sánchez J.M., Costillo E. \& Corbacho C. 2002. Blood chemistry and haematocrit of the black vulture (Aegypius monachus). Comp. Biochem. Physiol. A, Mol. Integrat. Physiol. 132:489-497. 